Tér és Társadalom 24. évf. 2010/1. 1-14. p.

Tér és Társadalom

XXIV. évf. 2010 1: 1-14

\title{
A KLÍMAVÉDELEM EDDIGI MÉRLEGE ÉS KILÁTÁSAI
}

\author{
(The so far Achievements of Climate Protection and \\ its Perspectives)
}

\section{ERDÖSI FERENC}

Kulcsszavak:

klímaváltozás klímapolitika klímavédelem alkalmazkodás stratégiaváltás globalizáció ÜHG-emisszió antropogén hatások

A klímapolitika két "frontja" közul korábban nyitott a megelözésen alapuló klímavédelem (mitigation) volt. Ez arra irányult, hogy az üvegházhatâsú gázok emissziójának csökkentésével lassítsa, illetve megállítsa a globális felmelegedéshez vezetö, az extrém időjárási jelenségek gyakoriságát és intenzitását növeló és ezzel az emberiségnek sokféle és súlyos kárt okozó klímavaltozást.

Azonban a nemzetközi (világszervezeti) és nemzeti keretekben folytatott küzdelem a klímaváltozás ellen (föként egyes ágazati és nagyhatalmi ellenérdekek miatt) nem vezetett eredményre. A számos nemzetközi egyezmény ellenére az emissziót nem sikerült a kellö mértékben csökkenteni, a felmelegedési folyamat pedig az elvárttal szemben felgyorsult. Ezért századunk elején a klimapolitika kénytelen volt megújítani a "második frontot": elötérbe került a klímához való alkalmazkodás.

Jelen tanulmány második része a Tér és Társadalom egy késöbbi szamában fog megjelenni. Következö cikkünkben (az elobbi gondolatok mentén) részletesebben foglalkozunk az éghajlat-politika ma mindennél idöszerübb oldalával, az alkalmazkodással, a benne rejlö lehetöségekkel.

Légkörünkben az ipari civilizáció óta végbement, az élővilágot/emberiséget különféle módon, mértékben és helyen kedvezőtlenül érintő, illetve veszélyeztető légköri változások közül az ózonpajzs kritikus mértékủ elvékonyodása és a savas esők keletkezése elleni küzdelem megnyugtató részeredményeket hozott. Ezekhez képest összehasonlíthatatlanul nagyobb és végtelenül nehezen kezelhetö gond a természetes (az ekliptikai paraméterek ingadozásából - „sarokvándorlásból” - adódó) klímaingadozásoknál már erősebbnek bizonyuló antropogén tényezők hatására (1. táblázat) bekövetkezö, alapvetően a világ legnagyobb részén felmelegedésben, szárazosodásban és időjárási szélsőségekben manifesztálódó globális klímaváltozás.

A globalizáció következményének is tekinthetö éghajlatváltozás (Kondorosi 2008) nem csupán a természeti környezetet, a gazdaságot és az emberi élet ökológiai feltételeit kedvezötlenül befolyásoló, hanem áttételesen a nemzetközi békét és biztonságot is veszélyeztető, minden más világproblémát megelőző, felkiáltójelet érdemlö, az egész Földet érintő jelenség - ahogyan arra többek között Al Gore (2006) is figyelmeztetett. Ennek ellenére a döntéshozók részéről a témához való viszonyulás többnyire abban merül ki, hogy korunk számos generális problémája közül csupán az egyiknek tartják a klímaváltozást, pedig a fő globális gondok közötti kapcsolat kevésbé horizontális, mint inkább hierarchikusan vertikális (1.ábra). 


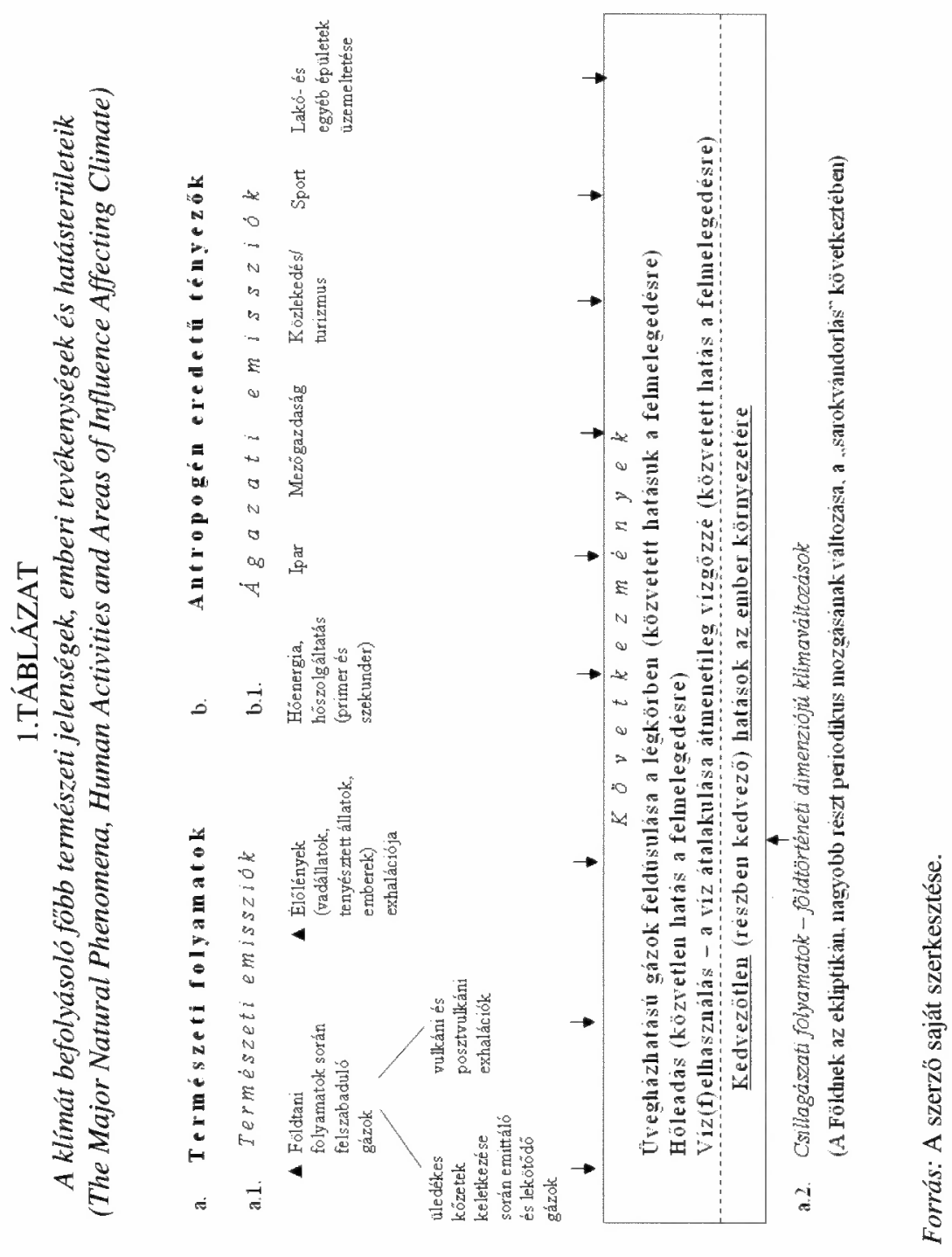


A klímavédelem...

\section{1. ÁBRA}

A klímaváltozás helye a globális problémák között kétfajta megközelítésben (The Placing of Climatic Change among Global Problems in Two Approaches)

I. Horizontális kapcsolatok az egyenló rangú tényezók között

$\begin{gathered}\text { Vízhiány, } \\ \text { földek } \\ \text { elhagyása }\end{gathered}-$ Éhínség
-

II. Vertikális kapcsolatok - a klímaváltozás egyenes következményei
1. Klímaváltozás
2. Politikai tényezők

$\downarrow$

Vízhiány, földek elhagyása

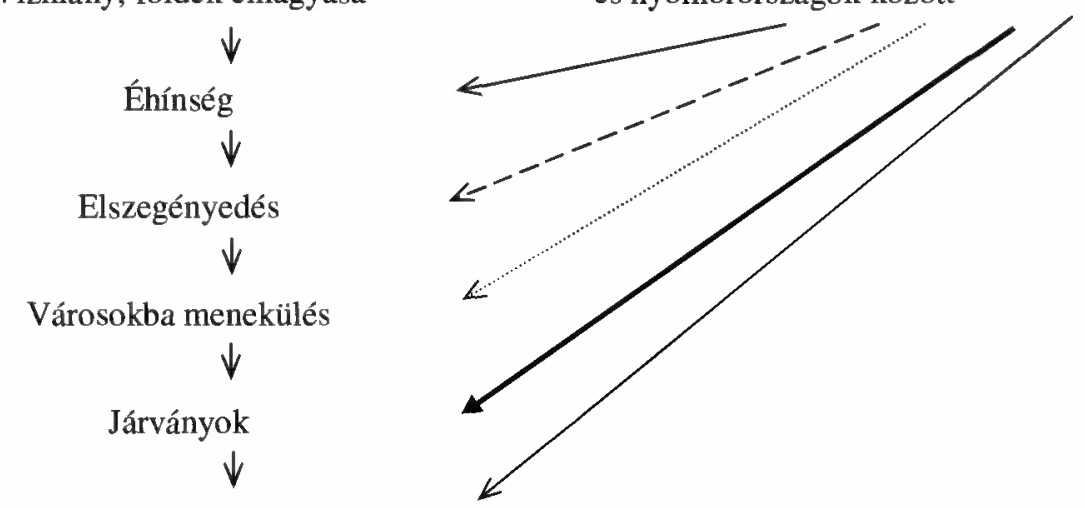

Fundamentalista terrorizmus

Forrás: A szerzỏ saját szerkesztése.

\section{A nemzetközi klímapolitika történetének fö idöszakai}

A klímavédelem történetében Faragó (2008) három időszakot különböztet meg:

- Az 1987 és 1992 közötti pionír idöszakot, amikor kormányok és világszervezetek hívták fel a figyelmet arra, hogy a környezeti problémák közül a klímaváltozás igényli a legnagyobb összefogást.

- Az 1993-1997. éveket a hivatkozott szerzö „nem elég” idôszaknak aposztrofálta, amikor az éghajlatváltozás veszélyének problémája ugyan bekerült a kiemelt jelentőségủ világpolitikai ügyek sorába, azonban jó néhány ország (különbözỏ okok miatt) nem volt hajlandó radikális változtatásokra.

- Az 1998-2006. évi „hezitálási idószak” elején kiderült, hogy az éghajlatváltozás gyorsulása miatt még a Kiotói Jegyzökönyvben rögzítetteknél is nagyobb mértékü kibocsátás-csökkentésre van szükség rövid időn belül, továbbá komoly figyelmet kell fordítani most már az alkalmazkodásra is. Az USA kezdeményezésére lehetőség nyílott a nemzetközi emisszió-kereskedelemre. Az EU 2005. évi állásfoglalása szerint meg kell akadályozni - az üvegház- 
hatású gázok (ÜHG) emissziójának még radikálisabb csökkentésével -, hogy a Föld átlagos hőmérséklete az ipari korszak előttihez képest $1{ }^{\circ} \mathrm{C}$-nál nagyobb mértékben növekedjen.

- A 2007. évet Faragó a lehetséges fordulat évének tartja az IPCC minden korábbinál részletesebb és meggyőző jelentésének megjelenésével, melynek nyomán az arra hamarosan pozitívan reagáló több, 2009. évi nemzetközi kormányfői konferencia magáévá tette a gyors cselekvés szükségességének parancsát, $2{ }^{\circ} \mathrm{C}$-ban maximálta a még kezelhetö felmelegedést 2100 -ig, és sor került a koppenhágai klímaértekezletre.

\section{A megelözés mint a klimavédelem alapja}

A ,kezelhetetlen elkerülése” (Szlávik 2008) érdekében végzett klímavédelem a megelőzésen alapul. A megelőzés (mitigation) lehetőségének két alapvető módja van, nevezetesen az ÜHG-kibocsátás mérséklése, visszafogása, továbbá az ÜHG elnyeletése („,közömbösítése”).

Meghatározó jelentôsége a gyakorlatban még jó ideig az emisszió visszafogásának lesz. Ennek

- közvetlen módja az épületek, üzemek, közlekedés müködtetésére, ipari/ mezőgazdasági termelésre, szolgáltatásokra stb. elhasznált szénalapú energiafelhasználás csökkentése elsősorban a $\mathrm{CO}_{2}$ mindenkori minimalizálása érdekében. E körbe tartozik a szennyvízkezelés és a hulladékgazdálkodás, az állattenyésztés stb. során a légkörbe direkt módon exhalálódó metán $\left(\mathrm{CH}_{4}\right)$ is.

A csökkentési elvárások egyaránt vonatkoznak

- az emisszió abszolút mennyiségére, akár a gazdasági teljesítmény visszafogásához is vezető „elegendőség” stratégia (Szlávik 2008) égisze alatt, továbbá

- a fajlagosra, (az egységnyi gazdasági tevékenységre jutó) ÜHGkibocsátás csökkentésével a „hatékonyság” stratégiájának is eleget téve.

- Az emisszió mérséklésének áttételes, közvetett módja a termelés (munkahelyek) és fogyasztás (lakóhelyek) közötti közlekedési távolság lerövidítése, azaz a funkciók térbeli közelebb telepítése egymáshoz

- a közlekedési emisszió csökkentése,

- továbbá többféle erőforrással/energiával való takarékosság (pl. a kisebb hủtési energia, a jármüvek élettartamának növelése) érdekében elsősorban a városi vonzásterületeken belüli, de akár interkontinentális viszonylatokban is. (A helyi/közeli a szép és a jó - global sourcing helyett localsourcing.) Lehet, hogy kibékíthetetlen ellentmondásban van a globális éghajlatváltozáshoz vezető globalizáció és a lokális/kistérség klímabarát ellátási rendszer? Ismét időszerü lenne Thünnen ideája? 
Az ÜHG-elnyeletés fokozásának, azaz a gázok légkörből való kivonásának természetes módjára, az erdőterületek lényeges növelésére globális szinten a közeljövőben aligha lesz mód, mert miközben némi eredményt érnek el e téren egyes fejlett és közepesen fejlett országok, ehhez képest többször nagyobb erdőket irtanak ki a harmadik világ országaiban, a FÁK-országokban.

Elméletileg ugyan a $\mathrm{CO}_{2}$-elnyelés mesterséges módjára is van müszaki lehetöség óriási abszorbeáló berendezések létesítésével, de ez a megoldás még alig jutott tovább az ötlet, illetve a vázlatos tervezés szintjénél.

\section{A klímavédelemre alapozó klímapolitika egyoldalúsága és kudarca világszerte}

A globalizáció és a klímaváltozás interdependens viszonyából következik, hogy az emberiség túlnyomó része számára nem kívánatos, valósággal sokkoló következményekkel járó, felgyorsult folyamatok ellen csak a világméretü, a nemzetközi összefogáson alapuló küzdelem járhat sikerrel. Ennek felismerése késztette a világszervezeteket és nemzeti kormányokat klímapolitikai lépésekre. Az érdemileg az 1980/90-es évek fordulójától kibontakozott klímapolitika központjában a változásokért fö felelősnek talált ÜHG kibocsátásának csökkentése állt. A csupán a klímavédelemre szorítkozó egyetlen ,front" nyitásával a klímapolitika jó ideig megelégedett a változásokat kiváltó okok megszüntetésére irányuló erófeszítésekkel, mindenekelött a $\mathrm{CO}_{2}$, továbbá az $\mathrm{NO}_{2}$ és $\mathrm{CH}_{4}$-emisszió ellen irányulókkal. Az ózonpajzshoz és savas esőkhöz képest a klímaváltozás azonban nehezen megfordítható vagy legalábbis leállítható, mivel a folyamatért felelös emissziók

- forrásai valamilyen formában és mértékben az egész Földön jelen vannak (túlnyomóan természetes formában még a tengereken is),

- a kibocsátást elöidézö fő tevékenységek (höerömüvek, kohászat, ipar, fütés/hütés, közlekedés, állattenyésztés, autósport) folytatásához, fenntartásához kőkemény (gazdasági, életminőséggel kapcsolatos) érdekek füződnek.

A kibocsátó pontszerủ (helyi) vagy vonalas létesítmények nemcsak hogy háromdimenziós hatást generálnak a légkörben, hanem összegeződve az egész Glóbusz éghajlatát képesek módosítani.

A helyzetfelismerés és az annak szellemében történő cselekvés között sajnálatos módon nagy különbségek mutatkoznak. A még az elvileg valamilyen szinten környezettudatos emberek is vagy az elkényelmesedés okán, vagy a különböző külső (fóként gazdasági) kényszerítő erők hatására elveiket feladva (vagy azokkal megalkudva) másként cselekszenek, engedményeket tesznek. 


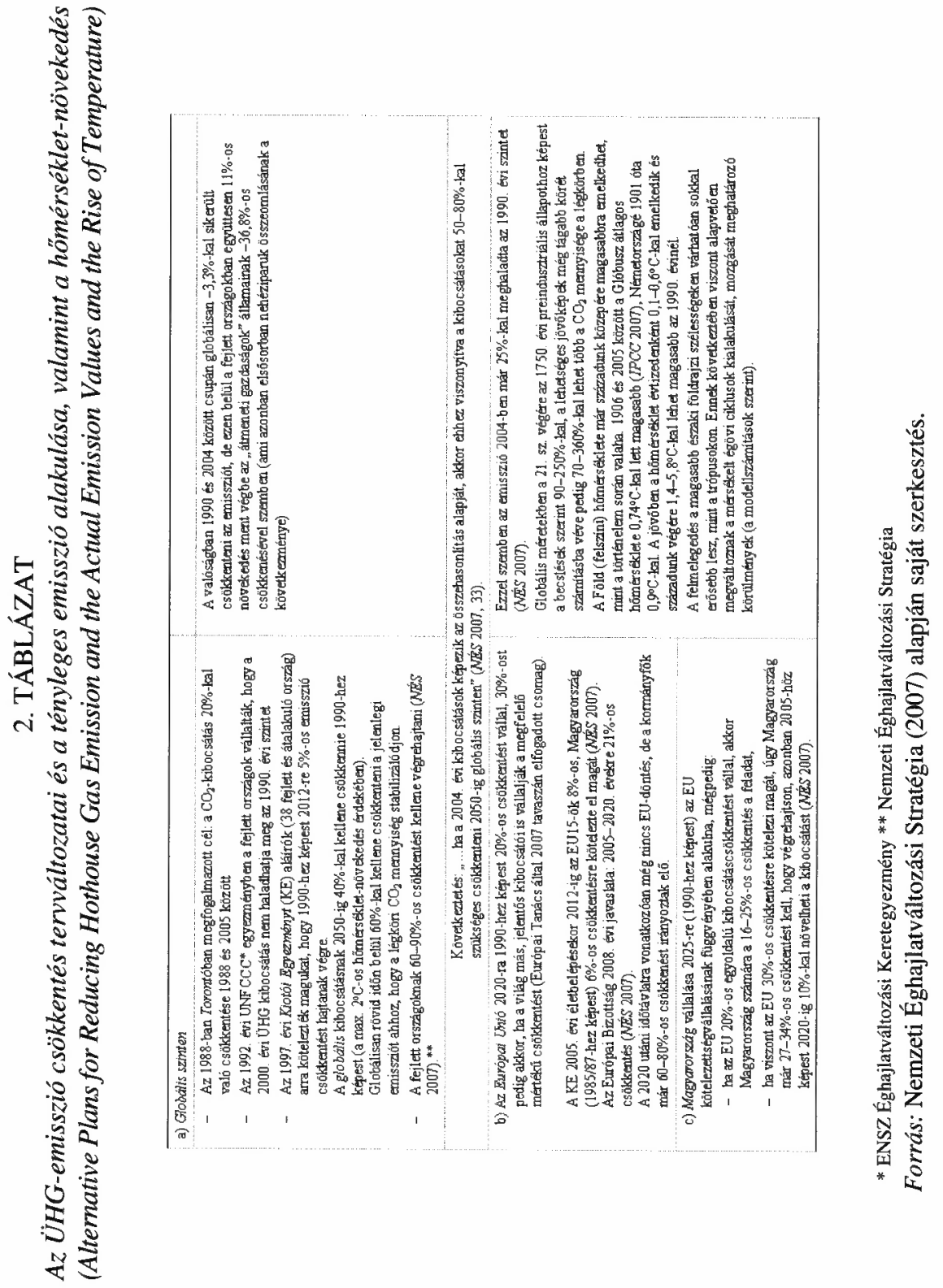


Bármennyire nagy (sok vonatkozásban tiszteletre méltó) erőfeszítések történtek is az ÜHG csökkentésének érdekében a nemzetközi egyezményeket tető alá hozók, a világkonferenciák szervezői és jó néhány nemzeti kormány részéről (2. táblâzat), a klímavédelmet szolgáló intézkedések méretükben és hatékonyságukban még a küszöbértéket sem érik el, ezért az éghajlat „rosszabbodása” a Föld legnagyobb részén folytatódik. Mindaddig, amíg a természetes éghajlat „torzulásához” vezető okokat (üzlet, hatalmi érdekek, a kényelem prioritása az életmódban stb.) nem sikerül kiiktatni, nem várható, hogy megindul a jobbító folyamat. A gazdasági növekedés a demográfiaival egyuitt a mai és a belátható jövőbeni általános technológiai szinten óhatatlanul valamilyen arányú (a légkört is kedvezötlenül befolyásoló) további környezetterheléssel jár. A klímavédelmi kiadásoktól való ódzkodásnak, illetve az azokra való korlátozott hajlandóságnak különleges motivációi is vannak, mint pl. a katonai, illetve ürkutatási kiadások felzárkóztatása az ország méreteihez, illetve nagyhatalmi pozíciójához, ahogy ez Kínában, részben Indiában történik.

\section{A klímaváltozás eddigi és várható fóbb területi jellemzői}

Földünk átlagos hömérséklete az ipari korszak beköszöntétől, az 1790-es évektöl 2006-ig 0,6 ${ }^{\circ} \mathrm{C}$-kal emelkedett az IPCC 2007. évi jelentése szerint. Ezzel szemben Solomon et al. (2007) csupán az utóbbi, 1906 és 2005 közötti mintegy száz évre $0,74{ }^{\circ} \mathrm{C}$-os melegedést mutatott ki. Az utóbbi idő második felében a folyamat már kétszer gyorsabb volt, mint korábban. A meteorológiai mérések kezdete óta számított tíz legmelegebb évböl pedig kilencet az 1990 óta eltelt másfél évtizedben regisztráltak!

A csapadékcsökkenés az 1960-as évektől kimutatható Afrika és Ázsia trópusi és szubtrópusi területein, mégpedig jelentős mértékben, 1980 óta pedig a világ szárazföldi területein tendenciaszerủen, de nagy területi különbségekkel. Növekedést csak viszonylag kevés helyen, pl. a Csendes-óceán mérsékelt övezeti területein mértek.

A tengerszint-emelkedés a sarkvidéki kontinentális jég olvadása és a felmelegedés miatti víztömegtágulás következtében az utóbbi 100-150 évben max. $20 \mathrm{~cm}-\mathrm{t}$ tett ki.

Németországban a 20 . században a léghömérséklet $1{ }^{\circ} \mathrm{C}$-kal lett melegebb, és 1901 óta az utóbbi tíz éven belüli $(1999,2000,2002,2006,2007$ és 2008) évek voltak a legmelegebbek (Daten des DWD 2008). A 2007. évi legerősebb hőhullámok még a „kiegyenlített éghajlatú” atlanti Nyugat-Európában is több tízezer ember halálát okozták.

Magyarországon 1975 és 2004 között a nyári max. hömérséklet 2-3 ${ }^{\circ} \mathrm{C}$-kal növekedett (NÉS 2007) és a hőhullámok gyakorisága az 1990-es évek óta növekszik: 1992 és 2000 között 6 hỏhullám következett be. A valaha mért leghosszabb és legmelegebb hőhullámot a lakosság 2007-ben szenvedte el, 5 napon keresztül $30^{\circ} \mathrm{C}$ felett volt a napi átlagos hömérséklet (Páldy-Bobvos 2008). A 2007. évi három höhullámból a második idején 38\%-kal (600-800 fővel) többen hunytak el.

Ugyan a jövőre vonatkozó modellszámítások adatai egymástól nem jelentéktelen mértékben különböznek, valamennyi szerint a változás folyamata gyorsuló, a 
hömérséklet hatványszerüen emelkedik. A globális hőmérséklet-emelkedést a 20. század végétől 2100-ig tartó időszakra $1,1-6,4{ }^{\circ} \mathrm{C}$ intervallumban adták meg a különböző források (a 2009. éviek már ennél is nagyobb felmelegedéssel számolnak). A 2025-ig terjedő két és fél évtizedre $1{ }^{\circ} \mathrm{C}$-kal számoltak (NÉS 2007), de a 2009. évi szcenáriók már a közeljövőben is gyorsabb melegedést valószínüsítenek.

Az IPCC 2007. évi rendkívül részletes előretekintést tartalmazó jelentéséből az egyes kontinensekre az alábbi föbb megállapítások tehetôk:

- A klímaváltozás várhatóan a legerősebben Afrikát érinti, mégpedig a Szahara északi és déli irányú terjeszkedésével, továbbá Fekete-Afrika északi régióiban és különösen Kelet-Afrikán belül nyugaton a Kalahári hódít újabb területeket, míg új jelenségként a korábban füves-cserjés, illetve szavanna vegetációjú Kelet-Afrikában megy végbe drámai, a félsivatagosodáshoz vezetô drasztikus szárazosodási folyamat. Afrika nagy édesvízi tavainak halállománya oly mértékben csökken, hogy elveszti a népélelmezésben betöltött jelentőségét.

- Kelet-, Délkelet-, Dél- és Közép-Ázsia vízellátásában meghatározó szerepe van a Himalája/Hindukus/Tien San stb. magashegységi hótömegek, gleccserek olvadékvizéből táplált folyamoknak. A magashegységi vízutánpótlás nagy részének elmaradása beláthatatlan következményekkel járhat a mezögazdaságra, különösen Indiában, Észak-Kínában, Közép-Ázsiában.

- Ugyancsak a magashegységből (Andokból) származó öntözővíz hiányával kell számolni Dél-Amerika nyugati sávjában, míg az Amazonas-medence keleti részén a trópusi őserdő szavannává degradálódhat 2050-ig. Részben a tengeráramlások átrendeződése következtében bekövetkező vízmelegedés oda vezethet, hogy eljelentéktelenedik a peremi partok elötti világjelentőségü halászat.

- Észak-Amerikát elsősorban a csapadékhullás még szélsőségesebbé válásának következményei (áradások, növényi kártevők tömegei) sújthatják.

- Óceánia alacsonyabb fekvésủ szigeteit, továbbá Bangladest a tengerszintemelkedés fenyegeti.

Európában a 2040-2050. években a Földközi-tenger térségében a nyári hömérséklet több mint $2,5^{\circ} \mathrm{C}$-kal növekedhet az 1961-1990. évek átlagához képest, miközben Közép-Európa legnagyobb részén csupán $1{ }^{\circ} \mathrm{C}$-nál valamivel kisebb emelkedést valószínűsít a REMO A 18 szcenárió. A téli hónapokban viszont az $1,5-2,0{ }^{\circ} \mathrm{C}$-os melegedés a Földközi-tengertől Skandináviáig csaknem egész Európára kiterjed. Csak az Atlanti-óceán közvetlen hatása alatt álló nyugati övezetben (az Egyesült Királyságban, Portugáliában, Spanyolország egyes részein) várható az átlagosnál kisebb téli hőmérséklet-növekedés. A 21. század utolsó évtizedére a felmelegedés értéke szinte az egész kontinensen (télen és nyáron egyaránt) eléri a $3{ }^{\circ} \mathrm{C}$-ot.

A csapadék mennyisége a 21. század derekára a Földközi-tenger térségében a felére esik vissza valamennyi évszakban, miközben Skandináviában télen akkor már több csapadékkal lehet számolni. A nyári hónapokra Észak- és Közép-Európa nagy részén is csapadékcsökkenés (pl. az Egyesült Királyságban több mint 30\%-os) várható 
az A1B szcenárió szerint - az Azori maximum észak felé történö áthelyeződése következtében. A 21. század végére a 2050-re érvényes trendek egész Európában felerősödnek oly módon, hogy a Mediterráneumtól egészen Dél-Skandináviáig a nyári csapadék mennyisége tovább csökken.

A hőmérsékleti szélsőségek várható fokozódására jellemzỏ a fagyos napok ( Tmin $<0{ }^{\circ} \mathrm{C}$ ) és a höségnapok ( $\operatorname{Tmax}>30^{\circ} \mathrm{C}$ ) ellenkező előjel szerinti alakulása. Az A1B szcenárió szerint a fagyos napok száma már egész Európában kevesebb, miközben a hőségnapoké 2100-ig 5-50-nel több lesz - csak Angliában és Skandináviában nem kell több hőségnappal számolni (Jacob 2009).

Az Európa déli felének évszakonkénti időjárási viszonyait befolyásoló mediterrán ciklonok útvonalának, gyakoriságának és intenzitásának utóbbi évtizedekbeli változása a klímaváltozás mozzanatának értékelhető, mely jelentős mértékủ regionális éghajlat-változást okozhat a közepes földrajzi szélességeken (Bartholy et al. 2007).

Az előbbiek tükrében a klímaváltozástól leginkább fenyegetett térség a Mediterráneum. Amennyiben a jelzett változások valóban bekövetkeznek, DélEurópa éghajlata nagyjából olyan lehet, mint a mai Észak-Egyiptomé, és a vízhiány olyan méreteket ölt, hogy a mezőgazdasági termelés a harmadára csökken, így nemhogy a turisták sok tízmilliós tömegeit, de a saját népességet sem tudja eltartani. (Európa többi nagytérségében várható változásokkal helyszüke miatt e helyen most nem foglalkozunk.)

Németországban évszázadunk végére a hömérséklet 2,5-3,5 ${ }^{\circ} \mathrm{C}$-kal növekszik. A legerősebben (több mint $4{ }^{\circ} \mathrm{C}$-kal) a déli és délkeleti országrészek melegszenek fel az 1961-1990. év átlagában, míg a Keleti-tengerhez közeli térségekben a felmelegedés $\left(2,8^{\circ} \mathrm{C}\right)$ valamivel erősebb lehet, mint az Északi-tenger partján $\left(2,5^{\circ} \mathrm{C}\right)$. Az évi csapadék mennyisége hosszú távon átlagosan keveset változik, de megoszlása jóval szélsőségesebben alakul. Télen több lesz a csapadék a déli és délkeleti országrészben, azonban ezen belül a magasabb hőmérséklet miatt jóval kevesebb hóra lehet számítani. A nyári csapadék viszont az ország legtöbb táján kevesebb lesz. (A legerősebb nyári szárazosodási folyamatra a déli és délnyugati, valamint az északkeleti országrészben lehet számítani [Jacob 2009]).

Magyarországon a 2071-2100. években minden évszakban melegedés várható, de a legerösebb nyáron $\left(4-5^{\circ} \mathrm{C}\right)$, a legkisebb tavasszal $\left(3,0-3,5^{\circ} \mathrm{C}\right)$. A hỏmérséklet emelkedése nyáron É-D irányban, télen és tavasszal $\mathrm{Ny}-\mathrm{K}$ irányban erősödik (Bartholy et al. 2007).

\section{A hazai Nemzeti Éghajlatváltozási Stratégia (NÉS) irreális céljai és a környezettudatosság kérdöjelei}

A 2007-ben készült, 2025-ig szóló NÉS-ben megfogalmazott célok egy része életszerütlen, megvalósítása sok tekintetben lehetetlen. Az egyik legfontosabb megállapítása szerint „Az egy före jutó ÜHG-kibocsátás nem haladja meg az ökológiailag fenntartható szintet." Holisztikus nézőpontból a fenntarthatóságnak igazából csak 
globális dimenziója van. Ezért lényegében közömbös, hogy mely országok idézik elö a klíma földi méretü fenntarthatóságát vagy éppen fenntarthatatlanságát, vesznek vagy eladnak-e emissziós kvótát. A fenntarthatóságért globális szinten folyik a küzdelem. (Arról nem is beszélve, hogy ha már a jelenlegi globális folyamat is veszéllyel fenyeget, akkor a fenntarthatóság említése inkább csak retorikának tünik.)

A NÉS-ben kitüzött villamosenergia- (ezen belül a háztartási) fogyasztás rendkívül ambiciózus csökkentése nemzetközi összehasonlításban is példátlan méretekben fogalmazódott meg az egyik fö célkitủzésként. Az energiaszerkezetünk megváltoztatásával összefüggő hazai emissziócsökkentési elképzelés csak valami csoda bekövetkeztével valósulhat meg, ha öszintén szembenézünk Magyarország mai és belátható időn belül ugrásszerüen nem változó társadalmi-gazdasági helyzetével: „.... jelenlegi villamos energia felhasználása 70\%-ban (kiemelés tőlem - E. F.) lecsökken, és a jelenlegi hő felhasználásának 5\%-ára lesz szükség a hálózati melegvíz elöállításához, illetve egyéb ipari folyamatok működtetéséhez. A lakásállomány közel 40\%-a már ÜHG-kibocsátás nélkül fog működni. A nem passzív technológiával készült házak kibocsátása is 75\%-ban csökken...” „...előtérbe kerül a nem motorizált közlekedés, valamint a tömegközlekedés...” ,....az ország erdősültsége 27,4\%-ra emelkedik..." (NÉS 2007, 22).

A kijelentő módban (kész tényként) felsorakoztatott várt eredmények magas eufémia-tartalmúak. Közülük leginkább még az erdősültség mennyiségi növelésének lehet realitása. Azonban e vonatkozásban is számolni kell a fajösszetétel degradációjával. A szárazosodás már a nem is távoli jövőben a dombvidéki bükkösök, gyertyános tölgyesek és a nyugati határ széli lucfenyvesek fennmaradását erősen veszélyezteti, ezért a következőkben az erdőtelepítések fö színterei a még kellő nedvességtartalmú (mélyfekvésủ) talajok lehetnek. Egyre nagyobb területeken a szárazságtủrő fajok (az alacsony használati értékü, a talajt savanyító akác, feketefenyő stb.) kényszerszerüen magasabb részarányával kell számolni (Mátyás 2009).

De hol vannak a garanciák a korunkbeli tapasztalatok és tendenciák alapján az energiafogyasztás ilyen méretü csökkentésére, illetve a légkört kímélö megújuló energiák széles körủ használatára (az atomenergián kívül - Paks V. és VI. blokk), illetve az épületek (különösen az értékes többemeletes budapesti és vidéki nagyvárosi stílépületek) igen nagy hányadának erősen energiatakarékossá tételére.

A közlekedés átalakulásáról megfogalmazottak az ideális helyzetet célozzák meg. E téren a megvalósulást még aggályosabbnak látjuk, amikor

- a tömegközlekedés részaránya évről évre kisebb, részben a vasúti és (menetrendi) autóbusz-közlekedési szolgáltatási kínálat mennyiségének csökkenése és minőségének folyamatos romlása folytán, ami a kereslet csökkenéséhez és az egyéni közlekedésre átálláshoz vezet;

- amikor az individualizmus egyik tárgyiasult formája és a mozgásszabadság megtestesítője a személygépkocsi, és amikor a globalizált kereskedelem térben rendkívül szövevényes szállítási hálózati textúrájának logisztikai feltételeit 
(just in time, revolving stock stb.) kiemelkedő fölénnyel csak a kamionok képesek teljesíteni (aránytalanul sok baleset elöidézése árán);

- amikor az autóipar a gazdaság „királya” (húzóágazata), melynek világválságkor megingott trónját óriási állami anyagi segítséggel szilárdítják meg;

- amikor a hazai közlekedéspolitika (az uniós elvárásokkal szemben) nem a környezetbarátabb, hanem a legnagyobb tömegü ÜHG-emissziót produkáló közúti közlekedést preferálja. (Autópályák építését a vasúti fỏvonalak mielőbbi, a gyors közlekedést lehetővé tevő teljes átépítésével szemben. A MÁV-tól 2009-ben ugyanakkora összeget, 40 Mrd Ft-ot vont el a kormány, mint amekkorával a kecskeméti Mercedes gyár építését támogatja.)

Egy nemzeti program megvalósulása nagyban függ a lakosság támogatottságától, hogy milyen népakarat áll mögötte. Abban a legtöbb kutató, szakpolitikus és gondolkodó polgár egy véleményen van, hogy a globális éghajlati katasztrófa (számszerúen az évi átlaghỏmérséklet $2{ }^{\circ} \mathrm{C}$-nál nagyobb mértékü növekedésének) elkerülésére csak gyökeres (a növekedés hajszolása helyett az eröforrásokkal/energiával szigorúan takarékoskodó, az energiatermelésben a valóban klímabarát megújuló energiákat előnyben részesítő) gazdaságpolitikai, életmódbeli, életeszménybeli stb. paradigmaváltással lehet esélye az emberiségnek. Ehhez azonban az emberek magatartásában a mainál feltétlenül jóval erösebb környezet-, illetve klímatudatosságra lenne szükség, hogy ne csak elvileg azonosuljanak a klímapolitika törekvéseivel, hanem következetes cselekedeteikben is tetten érhetöen tegyenek, küzdjenek is a maguk és még inkább utódjaik érdekében.

Egy 2006. évi hazai reprezentatív felmérés válaszadóinak igen nagy hányada ugyan fontosnak tartja az üvegházhatású gázok elleni védekezés legkülönbözőbb módjait, azonban a tényleges magatartása és a nyilatkozata között még meglehetösen nagy a különbség. (Pl. ugyan a megkérdezettek $46 \%$-a autóját ritkábban használná a klímavédelem érdekében [Mosoniné Fried et al. 2007], azonban a meghirdetett autómentes nap tökéletes kudarca, a kényelem felülkerekedése az ésszerúség felett, a néhányszáz méteres, illetve 1-2 km-es autózásokról való lemondás képtelensége cáfolja a válaszok őszinteségét.) Egy iparvidéki (tatabányai) középiskolában végzett attitủdés viselkedésvizsgálatból pedig az derült ki, hogy a klímaváltozást a tanulók döntő többsége világviszonylatban ugyan súlyos problémának tartja, de Magyarország és Tatabánya tekintetében már nem, vagyis valami távoli veszélyt lát csak benne. Nem érzékelik, hogy a globális folyamatok egyik alkotója a mi országunk is. Még megdöbbentőbb, hogy mennyire nem ismerik a klímaváltozás okait és az ellene tehető lépéseket. Az ezzel kapcsolatos tévhitek miatt a saját lehetőségeiket leginkább a szelektív hulladék-gyüjtésben, a szemetelés elkerülésében és (a legjobb esetben) a villanynyal való takarékosságban látják (Andocs-Takács-Sánta 2009). A tájékozottság hiánya tehát éppen az ,internetgenerációt" jellemzi, ami arra utal, hogy önmagában a világhálóhasználat gyakorisága és az intellektuális, illetve a társadalom léte szempontjából is fontos, használt ismeretek között nem elég szoros az összefüggés. 
A környezetvédelem (és ezen belül a klímavédelem) harmadlagos kérdés a magyarországi politikában, közéletben, tárcájának finanszírozása méltatlanul gyenge, vezetői erőtlenül képviselik az egész társadalom szempontjából fontos ügyet. Pedig a klímavédelem, a klímapolitika súlyos problémáival, a kibontakozás esélyeinek korlátozottságával valamilyen mértékig és szempontból valamennyi volt magyar környezetvédelmi miniszter tisztában volt és van. Ez derült ki a „Környezetvédelem” lap szerkesztőségében rendezett beszélgetésen, ahol a következö megállapítások hangzottak el: „Torz a közlekedési struktúránk”, „Nem várhatunk nagy paradigmaváltást, mert nem ébredt fel a hazai társadalom, de a politika sem”, „A multinacionális világ újfajta értékrendjébe nem tudjuk az új kihívások eszközrendszerét beépíteni", „Beszélhetünk klímavédelemröl, de a munkanélküliség réme sokkal nagyobb mozgatóerỏ az emberek számára”, „Társadalmi felemelkedés nélkül ne várjunk környezettudatosságot”, „A környezetvédelemnek az tehet a legrosszabbat, ha hitbeli kérdéssé válik... Azokban az országokban, ahol müködik a környezetvédelem, a politikának meghatározó szerepe van ebben" stb. (Környezetvédelem 2009, 5).

Bármennyire is érzékelik, illetve őszintén elismerik szakmai oldalról a gondok súlyosságát, (politikus) kormánytagként annak idején másként igyekeztek kommunikálni „kifelé” a helyzetet.

\section{A további klímaváltozásra való reagálás alternatívái}

Ellentétben az edđigi klímaváltozásokkal, melyekröl földi méretekben már meglehetősen részletes és eléggé megbízható információk állnak rendelkezésre, a jövőbeni várható változásokról sokféle (egymástól többé-kevésbé különböző) adat áll rendelkezésre (2. táblázat). Azonban még átlagolásukból is mindenképpen az következik, hogy gyorsuló felmelegedési folyamattal kell szembenéznünk, amennyiben az emberiség szoros összefogással és rövid időn belül nem képes változtatni a kiváltó okokon. Ma ott tartunk, hogy a szakértök között mind többen kételkednek e veszélyes folyamat megállításának lehetöségében, annak ellenére, hogy ahhoz a müszaki feltételek meglennének, de az ellenérdekeken kívül a megfelelő elkötelezettségen alapuló elhatározás, motiváltság, nemtörődömség („utánunk az özönvíz” fíling) szinte lebénítja (vagy legalábbis lefékezi) a helyes szándékokat.

Természetesen a klímaváltozás megállításával kapcsolatosan megnyilvánuló szkepszis mélysége a kutató specialisták körében nem egyforma:

- Hecht (2009) szerint ,a klímaváltozást nem kerülhetjük el teljesen”;

- Frommer (2009) már kategorikusabban fogalmaz: „a klímaváltozást már nem lehet feltartóztatni." Erre a következtetésre jutott az IPPC is a negyedik, 2007. évi jelentésében, mely szerint „Többé már nem kétséges, hogy az ÜHG-k antropogén eredetủ kibocsátása miatt a Föld éghajlatában a felmelegedés tovább folytatódik. Erre az éghajlati rendszer tehetetlensége miatt a következő évtizedekben még akkor is sor kerül, ha sikerül stabilizálni a mai szinten vagy akár csökkenteni is az emissziót." 
- Az Európai Bizottság szerint - ha elfogadjuk, hogy az ÜHG a felelős a felmelegedésért - a kibocsátások eddigi és a közeljövőre nagy biztonsággal elöre jelezhetỏ trendje alapján a klímaváltozás nem akadályozható meg (Kommission... 2007).

Lomborg (2007) szerint a folyamat ugyan eredményesen befolyásolható, azonban költségei olyan ijesztó nagyságúak lennének, és csak igen nagy időkéséssel érvényesülnének, hogy az elkerülési intézkedések helyett nagyobb mértékben az alkalmazkodásban elérhető eredményekre kellene inkább törekedni.

Szlávik (2008) pedig az alkalmazkodás alatt mindössze „az elkerülhetetlen kezelését" érti.

\section{A klímapolitika mai aspektusai, az alkalmazkodás elötérbe kerülése}

A klímapolitika öt aspektusa közül három közvetlenül a klímaváltozás következményeinek kezelésével kapcsolatos:

- Az éghajlati jellemzőkben, illetve időjárási elemekben, illetve a Föld vízháztartásában, a világtenger szintjében stb. eddig végbement és a jövőben várható globális, valamint regionális változások tudományos igényü feltárása, ezekben az emberi beavatkozások mértékének tisztázása, a tendenciák megállapítása (stratégiai elem). Ez interdiszciplináris tudományos kutatási feladat, a gyakorlati élet szereplőinek tapasztalatát és segítségét is felhasználva.

- A végbement klímaváltozások kedvezőtlen és kedvező természeti, gazdasági és társadalmi következményeinek a lehető legpontosabb felmérése (,,leltárba" vétele), az ember egészségében, az erőforrásokban, a növény- és állatvilág életfeltételeiben, az épített környezetben/tárgyakban okozott károk megismerése (stratégiai elem). A környezetvédelmi szakszolgálatok, a területi államigazgatás szervei és tudományos szférabeli értékelők kooperációja.

- Az éghajlatváltozás gyors lefolyású és heves (szélsőséges időjárási helyzetekkel kapcsolatos) jelenségeiből (árvíz, szélvihar stb.) adódó károk szervezett felszámolására való felkészülés, a helyreállítás szervezeti kereteinek és forrásainak biztosítása - döntően a katasztrófavédelemre alapozva (taktikai elem).

- A lassú és beláthatatlan idejủ klímaváltozás lassítása (esetleg megállítása) az ÜHG-emisszió csökkentésére alapozott klímavédelmi intézkedésekkel, melyek csak az egész Földre kiterjedö összefogással ígérhetnek esélyt a tényleges kedvező folyamatok megindulásához (stratégiai elem). Alapvetően makroközösségi (regionális, nemzeti, nemzetközi szervezeti) keretekben végzendỏ, szerteágazó feladat, de eredményessége nagyon függ az egyes személyek hozzáállásától.

A bekövetkezett és elöre láthatóan a jövőben még jó ideig elkerülhetetlen további éghajlatváltozásokhoz való alkalmazkodás (taktikai vagy éppen stratégiai elem) nagyobb részt az egyes személyek, csoportok, kollektívák döntéseire alapozható feladat. 
Végtelenül nehéz felelősségteljes döntést hozni a klímapolitika két frontja közötti arányokról. Erre utal Láng (2007) akadémikus is a költőinél erőteljesebb kérdésfelvetéssel: ,...csökkentés, alkalmazkodás, mindkettő?”

\section{Irodalom}

Andocs N.-Takács-Sánta A. (2009) Középiskolások klímaváltozással kapcsolatos attitüdjei és viselkekedése. - „KLIMA-21" Füzetek. 56. 76-90. o.

Bartholy J.-Pongrácz R.-Gelybó Gy. (2007) A 21. század végén várható regionális éghajlatváltozás Magyarországon. - Földrajzi Értesítö. 3-4. 147-168. o.

Daten des DWD. (2008) Deutscher Wetterdienst. www.dwd.de

Faragó T. (2008) Klímaváltozás és a nemzetközi cgyüttmüködés, - „KLÍMA- 21 " Füzetek. 52. 45-50. o.

Frommer, B. (2009) Handlungs- und Steuerungsfähigkeit von Städten und Regionen im Klimawandel. Raumforschung und Raumordnung. 2. 128-141.o.

Gore, A. (2006) Kellemetlen igazság. A bolygónkat fenyegető globális felmelegedés és leküzdésének lehetöségei. Göncöl Kiadó, Budapest.

Hecht, D. (2009) Anpassung an den Klimawandel, - Raumforschung und Raumordnung. 2. 157-169. o.

IPCC (2007) Intergovernmental Panel on Climate Change 2007. www.ipcc.ch

Jacob, D. (2009) Regionalisierte Szenarien des Klimawandels. - Raumforschung und Raumordnung. 2. 89-96. 0.

Komission der Europäischen Gemeinschaften. (2007) KOM 354. Európai Bizottság, Brüsszel.

Kondorosi F. (2008) Klímaváltozás és az emberi jogok. - KLÍMA-21" Füzetek. 52. 16-33. o.

Környezetvédelem. (2009) www.muszakilapok.hu/ujsag/kornyezetvedelem

Láng I. (2007) A klímapolitika rejtelmei: csökkentés, alkalmazkodás, mindkettő? - KLÍMA-2I" Füzetek. 49. 91-92. o.

Mátyás Cs. (2009) Klimatikus stressz és a fafajok genetikus válaszreakciója az elterjedés szárazsági határán. - KLÍMA-21" Füzetek. 56. 65-75. o.

Mosoniné Fried J.-Pálinkó É.--Stefan E. (2007) Klímaváltozás a közvéleménykutatások tükrében. KLIMA-21" Füzetek. 49.45-48. o.

NÉS (2007) Nemzeti Éghajlatváltozási Stratégia 2008-2025. Környezetvédelmi és Vízügyi Minisztérium, Budapest.

Páldy A.-Bobvos J. (2008) A 2007. évi magyarországi hỏhullámok gyakorisága. - KLÍMA-21" Füzetek. 52. 3-15. o.

Solomon, S.-Qin, D.-Manning, M.-Chen, Z.-Marquis, M.-Averyt, K.-Tigner, M.-Miller, H. (eds.) (2007) Climate Change 2007: The Physical Science Basis. Cambridge University Press, Cambridge-New York.

Szlávik J. (2008) A klímastratégia gazdasági kérdései. - KLÍMA- 21" Füzetek. 52. 34-44. o.

UNFCCC (1992) United Nations Framework Convention on Climate Change. ENSZ, Rió de Janeiró.

\section{THE SO FAR ACHIEVEMENTS OF CLIMATE PROTECTION AND ITS PERSPECTIVES}

\section{FERENC ERDÖSI}

Climate policy should be focused adaptation instead of protection but it is not known yet what concrete climatic conditions we should adjust to through the various forms of accommodation. Of the three components of adaptation the active relationship of human population to climatic changes is the most critical factor as even 'climate researchers' do very little about preventing or slowing down changes leading to harmful consequences. Without clearing the relationship between climate protection and the adaptation to climatic conditions climate policy may get on wrong track. Care should be taken for avoiding (technocracy-minded) adaptation methods not harmonising with climate protection. The selection of the most adequate adaptation strategy cannot be based on purely economic considerations. 